(c) American Dairy Science Association, 2004.

\title{
Effects of Fiber Content and Particle Size of Forage on the Flow of Microbial Amino Acids from Continuous Culture Fermenters*
}

\author{
M. Rodríguez-Prado, S. Calsamiglia, and A. Ferret \\ Departament de Ciència Animal i dels Aliments, \\ Universitat Autònoma de Barcelona. 08193 Bellaterra, Spain
}

\begin{abstract}
Eight dual-flow continuous culture fermenters (1320 $\mathrm{mL}$ ) were used in two 10-d consecutive periods to study the effects of fiber content and particle size on rumen fermentation, nutrient flow, and the profile and flow of amino acids (AA) from microbial origin. Treatments were arranged in a $2 \times 2$ factorial; the main factors were fiber content (high fiber $[\mathrm{HF}]=67 \%$ alfalfa hay, $33 \%$ concentrate; low fiber $[\mathrm{LF}]=39 \%$ alfalfa hay, $61 \%$ concentrate) and forage stem particle size (ground not to pass a $3-\mathrm{mm}$ sieve = large size [LS]; ground to pass a $1-\mathrm{mm}$ sieve $=$ small size [SS]). On the last day of the experiment, liquid- (LAB) and solid- (SAB) associated bacteria were isolated from each fermenter for chemical analysis. Microbial N and AA flows were estimated using $\mathrm{LAB}$ or SAB composition data. Total volatile fatty acid concentration was higher for LF (122 $\mathrm{mM})$ than for $\mathrm{HF}(102 \mathrm{mM})$. The proportion of acetate was higher for $\mathrm{HF}(63.5 \%)$ than for $\mathrm{LF}(58.2 \%)$. When SS was fed instead of LS, there was a reduction in the acetate proportion (63.4\% vs $58.3 \%$, respectively) and in the acetate to propionate ratio (3.13 vs. 2.41 , respectively). Bacterial $\mathrm{N}$ flow was higher, and dietary $\mathrm{N}$ flow was lower, in SS compared with LS when LAB were used for calculations. Efficiency of microbial protein synthesis (EMPS) was affected by particle size, when LAB were used for calculations, and by fiber content, when SAB were used for calculations. The AA profile of LAB differed from $\mathrm{SAB}$ in 4 of $16 \mathrm{AA}$. The fiber content and particle size had small effects on microbial AA profile. However, the bacterial AA flow was higher in 13 of 16 $\mathrm{AA}$, when $\mathrm{SAB}$ instead of LAB were used for calculations. Estimates of bacterial N flow, EMPS, AA profile, and flows of microbial origin were dependent on the type of microbial population used for calculations. The
\end{abstract}

Received August 7, 2003.

Accepted December 19, 2003.

Corresponding author: S. Calsamiglia; e-mail: sergio.calsamiglia @uab.es.

*Financial support provided by the Comision Interministerial de Ciencia y Tecnologia of the Spanish Government (Project AGF97/ 0444). representativeness of the microbial samples is essential for the accurate prediction of the AA flow from microbial origin.

(Key words: fiber, particle size, amino acid, rumen bacteria)

Abbreviation key: EAA = essential AA, EMPS = efficiency of microbial protein synthesis, $\mathbf{H F}=$ high fiber, $\mathbf{L A B}=$ liquid-associated bacteria, $\mathbf{L F}=$ low fiber, $\mathbf{L S}=$ large size, NEAA = non-essential AA, $\mathbf{S A B}=$ solidassociated bacteria, $\mathbf{S S}=$ small size.

\section{INTRODUCTION}

Feeding systems for dairy cattle (O'Connor et al., 1993; Rulquin and Vérité, 1993; NRC, 2001) include the prediction of AA requirements and supply to the small intestine. Between 50 and $80 \%$ of the AA flowing to the small intestine are of microbial origin (Storm and Ørskov, 1984). There is considerable evidence that the chemical composition (Clark et al., 1992; Martin et al., 1994; Pérez et al., 1998) and the AA profile (Lallès et al., 1992; Martin et al., 1996) of solid- (SAB) and liquid (LAB) associated bacteria differ. Our first objective was to determine the effect of using $\mathrm{LAB}$ or $\mathrm{SAB}$ on the estimated flow of AA from microbial origin. The hypothesis was that if the AA profiles of $\mathrm{SAB}$ and $\mathrm{LAB}$ are indeed different, diets that would be favorable to the growth of SAB (high fiber and small particles to increase microbial attachment surface) or LAB (low fiber and large particles to reduce the microbial attachment surface) will affect the partial contribution of each bacterial fraction and, therefore, their estimated contribution to the supply of AA to the small intestine.

A second objective was to study the direct effect of fiber content and particle size on rumen microbial fermentation. Results from in vivo studies indicate that as the level of fiber in the diet decreases, ruminal $\mathrm{pH}$, retention time, and fiber digestibility also decrease. However, the reduction in fiber digestibility cannot be attributed uniquely to the change in fiber content of the diet because the effects are confounded. Similarly, while the reduction in particle size has been associated with an increase in fiber digestion caused by greater 
Table 1. Ingredient and chemical composition of the diets.

\begin{tabular}{|c|c|c|c|c|}
\hline \multirow[b]{2}{*}{ Ingredient } & \multicolumn{4}{|c|}{ Diet $^{1}$} \\
\hline & $\mathrm{HF}+\mathrm{LS}$ & $\mathrm{HF}+\mathrm{SS}$ & $\mathrm{LF}+\mathrm{LS}$ & $\mathrm{LF}+\mathrm{SS}$ \\
\hline \multicolumn{5}{|l|}{ Alfalfa hay, ${ }^{2} \%$ of DM } \\
\hline Stem & 41.6 & 41.6 & 24.1 & 24.1 \\
\hline Leaf & 25.5 & 25.5 & 14.8 & 14.8 \\
\hline Corn grain (ground), \% of DM & 23.9 & 23.9 & 47.2 & 47.2 \\
\hline Soybean meal, $\%$ of DM & 7.3 & 7.3 & 11.3 & 11.3 \\
\hline Minerals and vitamins, ${ }^{3} \%$ of DM & 1.7 & 1.7 & 2.3 & 2.3 \\
\hline \multicolumn{5}{|l|}{ Chemical composition } \\
\hline DM, \% & 92.1 & 92.4 & 91.4 & 91.5 \\
\hline $\mathrm{OM}$ & 90.6 & 90.9 & 92.1 & 92.5 \\
\hline $\mathrm{CP}$ & 17.9 & 17.4 & 17.5 & 17.2 \\
\hline NDF & 40.1 & 40.2 & 28.1 & 29.6 \\
\hline $\mathrm{ADF}$ & 24.3 & 24.7 & 15.8 & 16.1 \\
\hline $\mathrm{NFC}^{4}$ & 31.9 & 34.0 & 45.0 & 44.0 \\
\hline \multicolumn{4}{|c|}{${ }^{1} \mathrm{HF}=$ High fiber, $\mathrm{LS}=$ large particle size, $\mathrm{SS}=$ small particle size, and $\mathrm{LF}=$ low fiber. } & ${ }^{2}$ Chemical composition of stems: $89.9 \% \mathrm{DM}, 6.0 \%$ ash, $9.13 \% \mathrm{CP}$, and $65.3 \mathrm{NDF}$. Chemical composition \\
\hline \multicolumn{5}{|c|}{$\begin{array}{l}{ }^{3} \mathrm{Contained} 17,000 \mathrm{ppm} \text { of Co, } 600 \mathrm{ppm} \text { of } \mathrm{Cu}, 2000 \mathrm{ppm} \text { of Fe, } 80 \mathrm{ppm} \text { of I, } 6000 \mathrm{ppm} \text { of } \mathrm{Mn}, 14 \mathrm{ppm} \text { of } \\
\text { Se, } 3000 \mathrm{ppm} \text { of } \mathrm{Zn}, 600 \mathrm{kIU} / \mathrm{kg} \text { of DM of vitamin A, } 120 \mathrm{kIU} / \mathrm{kg} \text { of DM of vitamin D, and } 360 \mathrm{IU} / \mathrm{kg} \text { of DM } \\
\text { of vitamin E. }\end{array}$} \\
\hline
\end{tabular}

surface for microbial attachment in situ (Nocek and Kohn, 1988), in vivo studies have reported lower fiber digestion, probably associated with an increased passage rate, a reduction in $\mathrm{pH}$ caused by lower rumination, or both. The isolation of these main factors independent of other changes in rumen conditions is essential for mathematical modelling of ruminal fermentation. In this context, the use of in vitro continuous culture systems offers the opportunity to change the fiber content or particle size without affecting intake, $\mathrm{pH}$, or dilution rates.

The objective of this research was to study the effects of fiber content and particle size on ruminal fermentation and nutrient flow and the profile and flow of $\mathrm{AA}$ from microbial origin using $\mathrm{LAB}$ or $\mathrm{SAB}$ composition data in a dual-flow continuous culture system.

\section{MATERIALS AND METHODS}

\section{Diets}

Four diets for lactating dairy cows were formulated with 2 levels of fiber content (high fiber $[\mathbf{H F}]=67$ to 33 alfalfa hay to concentrate ratio; low fiber $[\mathbf{L F}]=39$ to 61 alfalfa hay to concentrate ratio) and two forage stem particle sizes (large $[\mathbf{L S}]=$ ground not to pass a 3 -mm sieve; small [SS] = ground to pass a 1-mm sieve; Table 1). Diets were combinations of the 2 main factors $(\mathrm{HF}+\mathrm{LS}, \mathrm{HF}+\mathrm{SS}, \mathrm{LF}+\mathrm{LS}$, and $\mathrm{LF}+\mathrm{SS})$. Diets were designed with the intention of providing an extreme range of diets, where the surface available for the at- tachment of bacteria would change from small ( $\mathrm{LF}+$ $\mathrm{LS})$ to large (HF + SS). It was not the intention of this trial to study the effects of fiber content or particle size on rumen dynamic (salivation, rumination, etc.), but to isolate the effect of type of bacteria population on the flow of AA from microbial origin. The fiber source was early bloom alfalfa hay (Medicago sativa) for which stems and leaves were separated. The leaves were ground at $0.8 \mathrm{~mm}$. The stems were ground (hammer mill, Prat SA, Sabadell, Spain) and passed through a $3-\mathrm{mm}$ sieve. The sample retained in a $3-\mathrm{mm}$ sieve was divided in 2 equal parts. The first was considered as particle size $\geq 3 \mathrm{~mm}$, and the other was ground at 0.8 $\mathrm{mm}$ and totally passed through a $1-\mathrm{mm}$ sieve. This fraction was considered as $\leq 1 \mathrm{~mm}$. This process was conducted to guarantee that the compositions of the 2 particle sizes of alfalfa stems were similar. The alfalfa hay was reconstituted to a standard of $38 \%$ leaves and $62 \%$ stems (Jarrige et al., 1995).

\section{Continuous Culture System}

Eight 1320-mL dual-flow continuous culture fermenters (Hoover et al., 1976) were used in 2 consecutive 10d experimental periods. Fermenters were inoculated with ruminal fluid strained through 4 layers of cheesecloth taken from 2 ruminally cannulated cows fed a 50:50 alfalfa hay:concentrate diet. Experimental diets were mixed daily, and $95 \mathrm{~g}$ of DM were fed in 4 equal portions throughout the day. Temperature was main- 
tained at $39^{\circ} \mathrm{C}$, and $\mathrm{pH}$ was controlled at $6.4 \pm 0.05$ by infusion of $3 \mathrm{~N} \mathrm{HCl}$ or $5 \mathrm{~N} \mathrm{NaOH}$. The system was well buffered at $\mathrm{pH} 6.4$, and the average use of $\mathrm{HCl}$ and $\mathrm{NaOH}$ was of 12.0 and $12.5 \mathrm{~mL}$, respectively. Anaerobic conditions were maintained by infusion of $\mathrm{N}_{2}$ at a rate of $40 \mathrm{~mL} / \mathrm{min}$. Artificial saliva (Weller and Pilgrim, 1974) was continuously infused into flasks and contained $0.187 \mathrm{~g} / \mathrm{d}$ of nonprotein $\mathrm{N}$ to simulate recycled $\mathrm{N}$. Liquid and solid dilution rates were maintained at 10 and $5 \% / \mathrm{h}$, respectively.

\section{Sample Collection and Bacterial Detachment Procedure}

Each experimental period consisted of $7 \mathrm{~d}$ for adaptation and $3 \mathrm{~d}$ for sampling. During sampling days, collection vessels were maintained at $4^{\circ} \mathrm{C}$ to prevent microbial growth. Solid and liquid effluent content were homogenized for $1 \mathrm{~min}$, and a 500-mL sample was removed via aspiration. Upon completion of each period, effluents from the 3 sampling $d$ were composited and mixed within fermenter. Three subsamples of mixed effluent were taken; 2 of them were acidified with either $\mathrm{HCl}(4 \mathrm{~mL}$ of effluent in $4 \mathrm{~mL} 0.2 \mathrm{~N} \mathrm{HCl}$ ) or $\mathrm{H}_{3} \mathrm{PO}_{4}$ (4 mL of effluent in $1 \mathrm{~mL}$ of $0.2 \% \mathrm{HgCl}, 2 \%$ $\mathrm{H}_{3} \mathrm{PO}_{4}$, and $0.2 \%$ 4-methyl valerate) and frozen until analyzed for ammonia N and VFA concentrations, respectively. A 3rd subsample was taken in triplicate for total $\mathrm{N}$ analysis. Two $250-\mathrm{mL}$ portions of each composited sample were freeze-dried, ground through a 1-mm screen, and used for DM, ash, NDF, ADF, purine bases, and AA analysis.

Solid-associated bacteria and LAB were obtained the last day of each experimental period. The LAB were obtained by filtration of total fermenter flask contents through 2 layers of cheesecloth. The solid fraction was washed with saline solution $(0.85 \% \mathrm{wt} / \mathrm{vol} \mathrm{NaCl}$ in $3: 1$ saline solution:solid fraction) to remove residual bacteria of the liquid fraction (Olubobokun and Craig, 1990), and the filtrate was added to the LAB preparation. The filtrate was centrifuged for $10 \mathrm{~min}$ at $1000 \times g$ to remove feed residues. The supernatant fraction was centrifuged twice for $20 \mathrm{~min}$ at $20,000 \times \mathrm{g}$ to isolate $\mathrm{LAB}$, washed twice (once with $0.85 \%$ wt./vol. $\mathrm{NaCl}$ solution and another time with distilled water to reduce mineral contamination of the sample), and recentrifuged. The final bacterial pellet was freeze-dried for subsequent analysis. The SAB were obtained from the washed solid fraction by using a combination of several detachment procedures (Whitehouse et al., 1994) selected to obtain the maximum detachment without affecting cell integrity. The fermenter solid residue combined with the feed residue pellet obtained in the first centrifugation of the LAB separation procedure was suspended in a saline solution with $0.1 \%$ methylcellulose (3:1 saline solution:solid fraction) and incubated in a shaking water bath at $37^{\circ} \mathrm{C}$ for $30 \mathrm{~min}$ to remove attached bacteria (Minato and Suto, 1978). After the incubation, samples were refrigerated for $24 \mathrm{~h}$ at $4^{\circ} \mathrm{C}$, and solid residues were agitated for $1 \mathrm{~h}$ with marbles (thirty $2-\mathrm{mm}$ and fifteen 4-mm diameter marbles) to dislodge loosely attached bacteria. Finally, the solid fraction was filtered through cheesecloth and washed 3 times with saline solution. The SAB were obtained by differential centrifugation as in the LAB isolation procedure. The use of chemical (alcohol, formaldehyde, acids) or physical (homogenization) treatments (Whitehouse et al., 1994) was avoided to prevent changes in microbial cell integrity or modification in their AA composition.

\section{Sample Analyses}

The DM and ash contents in feed, bacteria, and effluents and the ether extract in diets were determined according to the AOAC (1990). The NDF and ADF concentrations in feed and effluents were determined sequentially (using a thermostable amylase; ANKOM Technology, Fairport, NY) and sodium sulfite (Van Soest et al., 1991). Total N in feed, effluents, and bacterial samples were determined by the Kjeldahl method (AOAC, 1990). The ammonia was determined by a colorimetric procedure (Chaney and Marbach, 1962). The VFA concentrations in deproteinized effluent fluid samples were determined by gas chromatography (GLC Hewlett Packard, Palo Alto, CA) using 4-methylvaleric as the internal standard (Jouany, 1982). The purine bases (adenine and guanine) in bacteria and effluent samples were determined by HPLC (Hewlett Packard) using allopurinol as the internal standard (Balcells et al., 1992). Bacteria (1 mg) and effluent samples (5 mg) for AA analysis were hydrolyzed with $200 \mu \mathrm{L}$ of $6 \mathrm{~N} \mathrm{HCl}$ at $110^{\circ} \mathrm{C}$ for $24 \mathrm{~h}$ in sealed, evacuated tubes. Stability of methionine residues was achieved by adding mercaptoethanol as a reducing agent. Derivatization was conducted with $200 \mathrm{nmol}$ per tube of dabsyl chloride at $70^{\circ} \mathrm{C}$ for $12 \mathrm{~min}$. The AA analysis was performed by reverse-phase HPLC (Beckmann Instruments, Palo Alto, CA) following the procedure of Vendrell and Avilés (1986), and using norleucine as the internal standard. A known mixture of free AA and a standard protein (lisozyme, L-687; Sigma-Aldrich, Madrid, Spain) were processed in duplicate within each run to correct for AA losses during hydrolysis and AA analysis. Recovery rates were used to correct the AA content of bacteria and effluents. The flow of AA from microbial origin was calculated as $\mathrm{g} \mathrm{AA} / \mathrm{d}=\mathrm{g} \mathrm{AA} / \mathrm{g} \mathrm{DM}$ bact $\times \mathrm{g}$ bact/d, where g AA/g DM bact is the AA content expressed in DM 
Table 2. Effects of fiber content and particle size of the diets on apparent and true OM, NDF, and ADF digestion in continuous culture.

\begin{tabular}{|c|c|c|c|c|c|c|c|}
\hline \multirow[b]{2}{*}{ Item } & \multicolumn{2}{|c|}{ Fiber content ${ }^{1}$} & \multicolumn{2}{|c|}{ Particle size } & \multirow[b]{2}{*}{$\mathrm{SEM}^{3}$} & \multicolumn{2}{|c|}{ Effect $(P<)$} \\
\hline & $\mathrm{HF}$ & $\mathrm{LF}$ & LS & SS & & Fiber & Size \\
\hline Apparent OM digestibility, $\%$ & 41.6 & 44.6 & 43.7 & 42.6 & 3.4 & NS & NS \\
\hline $\begin{array}{l}\text { True digestibility } \\
\mathrm{OM}_{\mathrm{LB}} \%\end{array}$ & 44.1 & 46.2 & 45.6 & 44.7 & 3.4 & NS & NS \\
\hline $\mathrm{OM}_{\mathrm{SAB}}, \%$ & 46.6 & 47.9 & 47.6 & 46.9 & 4.4 & NS & NS \\
\hline Fiber digestibility & & & & & & & \\
\hline NDF, \% & 27.9 & 30.0 & 31.6 & 26.3 & 8.1 & NS & NS \\
\hline $\mathrm{ADF}, \%$ & 26.7 & 27.6 & 30.2 & 24.0 & 8.1 & NS & NS \\
\hline
\end{tabular}

basis for $\mathrm{LAB}$ and $\mathrm{SAB}$, and $\mathrm{g}$ bact/d is the amount of bacterial DM synthesized daily.

\section{Statistical Analyses}

Data were analyzed as a randomized complete block design with a $2 \times 2$ factorial arrangement of treatments (Steel and Torrie, 1988). The model used for each dependent variable was

$$
\mathrm{Y}_{\mathrm{ijkl}}=\mu+\mathrm{B}_{\mathrm{i}}+\mathrm{F}_{\mathrm{i}}+\mathrm{S}_{\mathrm{k}}+(\mathrm{F} \times \mathrm{S})_{\mathrm{jk}}+\varepsilon_{\mathrm{ijkl}}
$$

where $\mu$ is the mean, $\mathrm{B}$ is the period as block, $\mathrm{F}$ is the fiber content effect, $\mathrm{S}$ is the particle size effect, and $\mathrm{F}$ $\times \mathrm{S}$ their interaction.

Statistical analysis was conducted using SAS (SAS Inst. Inc., Cary, NC). Microbial fermentation profile and nutrient flow data were analyzed using PROC GLM. Differences among means were tested by Tukey's multiple comparison test. The AA profile and flow of SAB and LAB were analyzed as a paired t-test (Steel and Torrie, 1988) using PROC MEANS. Differences were declared at $P<0.05$.

\section{RESULTS AND DISCUSSION}

\section{Chemical Composition of the Diets}

Diets were isonitrogenous; NDF and ADF levels were higher, and non-fiber carbohydrates were lower, in the HF diets compared with the LF diets, as expected (Table 1). The alfalfa fractionation and particle size reduction did not affect diet composition. Bowman and Firkins (1993) reported changes in nutrient composition with changes in feed particle size, which were probably due to the uneven distribution of small particles. The careful separation of leaves and stems and the complete grinding of well-defined stem fractions in the present experiment prevented these differences from happening.

Table 3. Effects of fiber content and particle size of the diets on VFA in continuous culture.

\begin{tabular}{|c|c|c|c|c|c|c|c|}
\hline \multirow[b]{2}{*}{ Item } & \multicolumn{2}{|c|}{ Fiber content ${ }^{1}$} & \multicolumn{2}{|c|}{ Particle size ${ }^{2}$} & \multirow[b]{2}{*}{ SEM } & \multicolumn{2}{|c|}{ Effect $(P<)$} \\
\hline & $\mathrm{HF}$ & $\mathrm{LF}$ & LS & SS & & Fiber & Size \\
\hline Total VFA, $\mathrm{m} M$ & 102.2 & 121.6 & 112.1 & 111.8 & 8.7 & $* *$ & NS \\
\hline Individual VFA, mol/100 mol & & & & & & & \\
\hline Acetate & 63.5 & 58.3 & 63.4 & 58.3 & 3.7 & $*$ & $*$ \\
\hline Propionate & 21.5 & 25.2 & 22.2 & 24.5 & 4.5 & NS & NS \\
\hline Butyrate & 10.9 & 11.8 & 9.9 & 12.9 & 1.4 & NS & $* *$ \\
\hline Iso-butyrate & 0.67 & 0.80 & 0.79 & 0.68 & 0.1 & $\dagger$ & $\dagger$ \\
\hline Valerate & 2.45 & 2.32 & 2.48 & 2.30 & 0.2 & NS & $\dagger$ \\
\hline Iso-valerate & 1.05 & 1.62 & 1.28 & 1.39 & 0.4 & * & NS \\
\hline Branched-chain VFA & 1.72 & 2.42 & 2.08 & 2.07 & 0.5 & * & NS \\
\hline Acetate:propionate & 3.05 & 2.49 & 3.13 & 2.41 & 0.6 & $\dagger$ & * \\
\hline
\end{tabular}

${ }^{1} \mathrm{HF}=$ High fiber; LF = low fiber.

${ }^{2} \mathrm{LS}=$ Large particle size; $\mathrm{SS}=$ small particle size.

$\dagger P<0.10$.

$* P<0.05$.

$* * P<0.01$ 
MICROBIAL AMINO ACID FLOW IN VITRO

Table 4. Effects of fiber content and particle size of the diets on $\mathrm{N}$ metabolism in continuous culture.

\begin{tabular}{|c|c|c|c|c|c|c|c|}
\hline \multirow[b]{2}{*}{ Item } & \multicolumn{2}{|c|}{ Fiber content ${ }^{1}$} & \multicolumn{2}{|c|}{ Particle size $^{2}$} & \multirow[b]{2}{*}{ SEM } & \multicolumn{2}{|c|}{ Effect $(P<)$} \\
\hline & $\mathrm{HF}$ & $\mathrm{LF}$ & LS & SS & & Fiber & Size \\
\hline Ammonia N, mg/100 mL & 17.8 & 18.6 & 18.6 & 17.8 & 3.5 & NS & NS \\
\hline Total N flow, g/d & 3.02 & 3.01 & 3.00 & 3.03 & 0.1 & NS & $\mathrm{NS}$ \\
\hline Ammonia $\mathrm{N}$ flow, $\mathrm{g} / \mathrm{d}$ & 0.56 & 0.58 & 0.58 & 0.56 & 0.1 & NS & NS \\
\hline Non-ammonia N flow, g/d & 2.46 & 2.43 & 2.42 & 2.47 & 0.1 & NS & NS \\
\hline \multicolumn{8}{|l|}{ Purine bases:N, $\mu \mathrm{mol} / \mathrm{g} \mathrm{N}$} \\
\hline $\mathrm{LAB}^{3}$ & 20.1 & 24.5 & 24.5 & 23.2 & 4.2 & $\dagger$ & $\dagger$ \\
\hline $\mathrm{SAB}^{3}$ & 24.3 & 18.8 & 20.1 & 19.9 & 5.1 & $\dagger$ & NS \\
\hline \multicolumn{8}{|l|}{ Dietary $\mathrm{N}$ flow, g/d } \\
\hline $\mathrm{LAB}$ & 1.32 & 1.42 & 1.46 & 1.29 & 0.1 & NS & $*$ \\
\hline $\mathrm{SAB}$ & 1.17 & 1.41 & 1.35 & 1.23 & 0.3 & $\dagger$ & NS \\
\hline \multicolumn{8}{|l|}{ Bacterial N flow, g/d } \\
\hline $\mathrm{LAB}$ & 1.13 & 1.00 & 0.96 & 1.18 & 0.2 & NS & * \\
\hline $\mathrm{SAB}$ & 1.29 & 1.02 & 1.08 & 1.24 & 0.3 & NS & $\mathrm{NS}$ \\
\hline \multicolumn{8}{|l|}{ Protein degradation, \% } \\
\hline LAB & 51.9 & 46.9 & 46.7 & 52.1 & 7.2 & NS & $\mathrm{NS}$ \\
\hline $\mathrm{SAB}$ & 57.5 & 47.5 & 50.7 & 54.3 & 10.6 & $\dagger$ & NS \\
\hline \multicolumn{8}{|l|}{ EMPS, ${ }^{4} \mathrm{~g} / \mathrm{kg}$ OMTD } \\
\hline $\mathrm{LAB}$ & 30.9 & 27.5 & 27.0 & 31.3 & 3.8 & NS & * \\
\hline $\mathrm{SAB}$ & 33.3 & 26.8 & 28.8 & 31.3 & 3.8 & $* *$ & NS \\
\hline
\end{tabular}

\footnotetext{
${ }^{1} \mathrm{HF}=$ High fiber; $\mathrm{LF}=$ low fiber.

${ }^{2} \mathrm{LS}=$ Large particle size; $\mathrm{SS}=$ small particle size.

${ }^{3} \mathrm{LAB}=$ Liquid-associated bacteria; $\mathrm{SAB}=$ solid-associated bacteria.

${ }^{4}$ EMPS = Efficiency of microbial protein synthesis (g N/kg OM truly digested [TOMD]).

$\dagger P<0.10$.

$* P<0.05$.

$* * P<0.01$
}

Because there were no interactions between fiber content and particle size $(P>0.10)$, main effects are presented and discussed, unless otherwise indicated.

\section{Digestibility Coefficients}

Fiber content did not affect apparent or true $\mathrm{OM}$ and fiber digestion, although it was numerically higher in LF (Table 2) than in HF. In contrast, fiber digestion decreased in vivo as the content of fiber decreased in the diet (Bourquin et al., 1994). Under in vivo conditions, low fiber diets resulted in a decrease in ruminal $\mathrm{pH}$, and the cause of the decrease in fiber digestion was confounded between fiber level and $\mathrm{pH}$ (Hoover, 1986). In the present trial, the lack of effect of treatments on fiber digestion when $\mathrm{pH}$ was controlled suggests that the reduction in fiber digestion observed in vivo was due to changes in $\mathrm{pH}$ rather than a direct effect of fiber content.

Particle size did not affect the apparent or true digestion of OM or fiber (Table 2). In vivo, the reduction in particle size has often been related to a decrease in ruminal degradation of DM, probably because of a lower retention time of feed particles in the rumen or a decrease in $\mathrm{pH}$ (Grant et al., 1990). In contrast, in vitro studies have shown that a reduction in particle size results in an increase in ruminal degradation of DM and fiber (Fahey et al., 1993), which was attributed to an increase in the surface area available for microbial attack (Bowman and Firkins, 1993) and the prevention of the changes in $\mathrm{pH}$ and dilution rates observed in vivo. Under the conditions of the present experiment, it is likely that the control of $\mathrm{pH}$ and dilution rates resulted in no differences in $\mathrm{OM}$ and fiber digestion. These results suggest that most changes observed in vivo on $\mathrm{OM}$ and fiber digestion caused by the content of fiber and particle size are mediated through changes in $\mathrm{pH}$ or dilution rates. Therefore, mechanistic models may predict accurately these effects by proper simulation of $\mathrm{pH}$ and dilution rate effects on nutrient digestion.

\section{Effects on Ruminal Fermentation}

VFA concentration. Total VFA concentration was higher $(P<0.05)$ in LF than in HF (Table 3$)$ and is consistant with the non-significant trend for higher OM digestion in LF (Table 2). In vivo (Bourquin et al., 1994) and in vitro (Russell, 1998) studies reported that low fiber diets resulted in higher VFA concentration because of the greater rate of fermentation of starch compared with fiber. Molar proportion of acetate was higher, and that of branched-chain VFA was lower, in HF than in LF diets $(P<0.05)$ and was consistent with 
Table 5. Chemical composition of solid- (SAB) and liquid-associated bacteria (LAB) in continuous culture.

\begin{tabular}{|c|c|c|c|c|}
\hline \multirow[b]{2}{*}{ Variable } & \multicolumn{2}{|c|}{ Bacteria } & \multirow[b]{2}{*}{$\mathrm{SEM}^{1}$} & \multirow[b]{2}{*}{$P<$} \\
\hline & $\mathrm{LAB}$ & $\mathrm{SAB}$ & & \\
\hline Bacterial N, \% & 9.37 & 8.71 & 0.18 & $* *$ \\
\hline $\mathrm{PB},{ }^{2} \mu \mathrm{mol} / \mathrm{g} \mathrm{DM}$ & 209.7 & 188.3 & 7.7 & $* *$ \\
\hline $\mathrm{PB}: \mathrm{N}, \mu \mathrm{mol} / \mathrm{g} \mathrm{N}$ & 22.28 & 21.55 & 0.87 & NS \\
\hline Bacterial N flow, ${ }^{3} \mathrm{~g} / \mathrm{d}$ & 1.07 & 1.16 & 0.06 & NS \\
\hline EMPS $^{4}$ & 29.18 & 30.03 & 0.17 & NS \\
\hline \multicolumn{5}{|c|}{ AA profile, g AA/100 g AA } \\
\hline Asp & 9.95 & 10.57 & 0.20 & $* *$ \\
\hline Glu & 8.26 & 8.40 & 0.11 & NS \\
\hline Ser & 5.84 & 5.86 & 0.09 & NS \\
\hline Thr & 6.17 & 6.10 & 0.08 & NS \\
\hline Gly & 10.05 & 10.19 & 0.31 & NS \\
\hline Ala & 11.34 & 11.52 & 0.07 & $*$ \\
\hline Arg & 3.51 & 3.62 & 0.04 & $* *$ \\
\hline Pro & 4.11 & 4.18 & 0.07 & NS \\
\hline Val & 5.63 & 5.53 & 0.07 & NS \\
\hline Met & 1.25 & 1.22 & 0.04 & NS \\
\hline Ile & 4.81 & 4.65 & 0.10 & NS \\
\hline Leu & 6.26 & 6.17 & 0.06 & NS \\
\hline Phe & 3.50 & 3.49 & 0.03 & NS \\
\hline Lys & 12.06 & 11.34 & 0.18 & $* * *$ \\
\hline His & 2.53 & 2.61 & 0.05 & $\dagger$ \\
\hline Tyr & 4.41 & 4.53 & 0.06 & $\dagger$ \\
\hline EAA $^{5}$ & 45.73 & 44.75 & 0.33 & ** \\
\hline $\mathrm{NEAA}^{6}$ & 54.27 & 55.25 & 0.33 & $* *$ \\
\hline
\end{tabular}

${ }^{1}$ Standard error of the mean of differences between SAB and LAB.

${ }^{2} \mathrm{~PB}=$ Purine bases $(\mu \mathrm{mol}$ [Adenine + Guanine] $/ \mathrm{g} \mathrm{DM})$.

${ }^{3}$ Total $\mathrm{N}$ flow of microbial origin.

${ }^{4} \mathrm{EMPS}=$ Efficiency of microbial protein synthesis.

${ }^{5} \mathrm{EAA}=$ Essential AA (Thr, Arg, Val, Met, Ile, Leu, Phe, Lys, and His).

${ }^{6} \mathrm{NEAA}=$ Nonessential AA (Ala, Asp, Glu, Gly, Pro, Ser, and Tyr).

$\dagger P<0.10$.

$* P<0.05$.

$* * P<0.01$

$* * * P<0.001$.

previous reports (Bourquin et al., 1994), as was the trend for lower acetate:propionate in the LF diets $(P<$ 0.10; Siciliano-Jones and Murphy, 1989; Russell, 1998).

Total VFA concentration was not affected by particle size. However, the proportion of acetate and acetate:propionate was higher in LS, and the butyrate concentration was lower in LS, compared with $\mathrm{SS}(P<0.05$; Table 3). Although the increase in the surface area for attachment of bacteria in SS did not increase fiber digestion and acetate concentration as expected (Bowman and Firkins, 1993), the higher butyrate concentration may justify, at least in part, the reduction in acetate concentration.

A reduction in acetate:propionate is often observed in in vivo experiments as a result of forage processing (Fahey et al., 1993). This has been implicated as the reason for the reduction in milk fat percentage often observed when lactating dairy cattle consume processed forages (Shaver et al., 1986). However, these observations in vivo are likely indirect effects of changes in $\mathrm{pH}$.
Grant et al. (1990) reported a reduction in acetate:propionate when cows were fed small particle forage, but the effect was attributed to the reduction of $\mathrm{pH}$ and the resulting increase in propionate. In the present experiment, the decrease in acetate:propionate in SS was due to a decrease in acetate. It should be noted that the decrease in acetate proportion in SS was parallel to an increase in butyrate concentration, suggesting that there was an increase in the conversion of acetate to butyrate in the SS diets.

$\boldsymbol{N}$ metabolism. Fiber content and particle size did not affect the ammonia $\mathrm{N}$ concentration or the flow of total, ammonia and nonammonia $\mathrm{N}(P>0.05$; Table 4$)$. Dietary and microbial $\mathrm{N}$ flow, protein degradation, and the efficiency of microbial protein synthesis (EMPS) were estimated using the chemical composition of LAB and SAB independently. Results are dependent of purine bases: $\mathrm{N}$ in $\mathrm{LAB}$ and $\mathrm{SAB}$, which tended to be affected by fiber content and particle size, when LAB were 
Table 6. Effect of fiber content and particle size of diets on amino acid flow (g/d) in continuous culture.

\begin{tabular}{|c|c|c|c|c|c|c|c|}
\hline \multirow[b]{2}{*}{$\mathrm{AA}$} & \multicolumn{2}{|c|}{ Fiber content ${ }^{1}$} & \multicolumn{2}{|c|}{ Particle size $^{2}$} & \multirow[b]{2}{*}{ SEM } & \multicolumn{2}{|c|}{ Effect $(P<)$} \\
\hline & $\mathrm{HF}$ & $\mathrm{LF}$ & LS & SS & & Fiber & Size \\
\hline Asp & 1.94 & 2.07 & 2.03 & 1.97 & 0.20 & $*$ & NS \\
\hline Glu & 2.20 & 2.49 & 2.38 & 2.31 & 0.23 & $*$ & NS \\
\hline Ser & 0.87 & 0.92 & 0.90 & 0.88 & 0.08 & NS & NS \\
\hline Thr & 0.92 & 0.98 & 0.96 & 0.94 & 0.09 & NS & NS \\
\hline Gly & 0.94 & 0.97 & 0.96 & 0.95 & 0.09 & NS & NS \\
\hline Ala & 1.32 & 1.46 & 1.41 & 1.38 & 0.16 & NS & NS \\
\hline Arg & 0.92 & 0.99 & 0.92 & 0.99 & 0.16 & NS & NS \\
\hline Pro & 0.70 & 0.75 & 0.74 & 0.72 & 0.08 & NS & NS \\
\hline Val & 1.04 & 1.13 & 1.09 & 1.08 & 0.11 & NS & NS \\
\hline Met & 0.27 & 0.28 & 0.29 & 0.26 & 0.04 & NS & NS \\
\hline Ile & 0.89 & 0.96 & 0.93 & 0.93 & 0.10 & NS & NS \\
\hline Leu & 1.41 & 1.55 & 1.49 & 1.47 & 0.14 & $\dagger$ & NS \\
\hline Phe & 0.84 & 0.88 & 0.88 & 0.84 & 0.09 & NS & NS \\
\hline Lys & 0.92 & 0.95 & 0.94 & 0.92 & 0.10 & NS & NS \\
\hline His & 0.29 & 0.29 & 0.29 & 0.29 & 0.03 & NS & NS \\
\hline Tyr & 0.66 & 0.75 & 0.72 & 0.68 & 0.06 & $*$ & NS \\
\hline $\mathrm{EAA}^{3}$ & 7.48 & 8.02 & 7.80 & 7.71 & 0.73 & NS & NS \\
\hline $\mathrm{NEAA}^{4}$ & 8.63 & 9.40 & 9.14 & 8.89 & 0.85 & $\dagger$ & NS \\
\hline Total & 16.11 & 17.42 & 16.94 & 16.60 & 1.57 & NS & NS \\
\hline
\end{tabular}

${ }^{1} \mathrm{HF}=$ High fiber; $\mathrm{LF}=$ low fiber.

${ }^{2} \mathrm{LS}=$ Large particle size; $\mathrm{SS}=$ small particle size.

${ }^{3} \mathrm{EAA}=$ Essential AA (Thr, Arg, Val, Met, Ile, Leu, Phe, Lys, and His).

${ }^{4} \mathrm{NEAA}=$ Nonessential AA (Ala, Asp, Glu, Gly, Pro, Ser, and Tyr).

$\dagger P<0.10$.

$* P<0.05$.

$* * * P<0.0001$.

used for calculation, and by fiber content, when SAB were used (Table 4).

The fiber content did not affect flow $(\mathrm{g} / \mathrm{d})$ of microbial $\mathrm{N}$ and tended $(P<0.10)$ to reduce dietary $\mathrm{N}$ flow and increase dietary CP degradation in HF compared with LF when SAB were used in calculations. The EMPS was higher $(P<0.05)$ in HF than in LF when SAB were used for calculation. Although the numerical trends were similar between data obtained using $\mathrm{LAB}$ or $\mathrm{SAB}$, differences were only significant when SAB data were used in calculations. Many authors (Hvelplund and Madsen, 1985; Rode et al., 1985) reported that high forage diets fed in vivo result in higher EMPS. In contrast, results of Bourquin et al. (1994) indicated lower EMPS in vivo when a $90 \%$ vs. $60 \%$ forage diet was fed. Meng et al. (1999) observed in continuous culture that diets with a high concentration of structural carbohydrates resulted in higher EMPS than diets with a high non-structural carbohydrate concentration, which agrees with the results obtained in the present trial.

The reduction in particle size resulted in lower dietary $\mathrm{N}$ flow and higher microbial $\mathrm{N}$ flow when $\mathrm{LAB}$ composition data were used in calculations $(P<0.05)$, although these differences did not result in significant differences in dietary CP degradation. The EMPS was lower in LS than in SS, although it was only significant when LAB composition data were used in calculations
$(P<0.05$; Table 4$)$. Results from in vivo trials have shown no consistent effects of forage particle size on the EMPS. Beever et al. (1981) observed no effects of forage particle size on the EMPS. In contrast, Rode et al. (1985) found that grinding and pelleting alfalfa hay resulted in a 15\% increase in EMPS in lactating dairy cows, but the higher EMPS was attributed to a faster solid dilution rate. However, in the present trial, solid dilution rate was maintained constant. Reduced particle size also results in increased surface area for microbial attachment and digestion (Bowman and Firkins, 1993) and may enhance energy availability and microbial growth, which may explain the higher EMPS observed in SS than in LS, although differences were only significant when LAB composition was used in calculations.

Chemical composition of LAB and SAB indicates differences in $\mathrm{N}$ and purine concentration; both were higher in LAB compared with SAB. However, N:purine was not different between microbial populations (Table 5). The higher mean $\mathrm{N}$ and purine concentrations in LAB vs. SAB in the present trial have already been reported by others (Olubobokun et al., 1988; Pérez et al., 1998). The higher purine concentration in LAB might reflect a higher rate of protein synthesis and, most probably, a higher growth rate than in SAB (Czerkawski, 1986; Legay-Carmier and Bauchard, 1989). 
Table 7. Effect of fiber content and particle size of the diets on AA profile (g AA/100 g AA) of liquid-associated bacteria $(\mathrm{LAB})$ and solid-associated bacteria $(\mathrm{SAB})$ in continuous culture.

\begin{tabular}{|c|c|c|c|c|c|c|c|c|}
\hline \multirow{2}{*}{ AA } & & \multicolumn{2}{|c|}{ Fiber content ${ }^{1}$} & \multicolumn{2}{|c|}{ Particle size $^{2}$} & \multirow[b]{2}{*}{ SEM } & \multicolumn{2}{|c|}{ Effect $(P<)$} \\
\hline & & $\mathrm{HF}$ & $\mathrm{LF}$ & LS & SS & & Fiber & Size \\
\hline \multirow[t]{2}{*}{ Asp } & $\mathrm{LAB}$ & 10.4 & 9.5 & 9.8 & 10.1 & 0.5 & $* *$ & $\mathrm{NS}$ \\
\hline & SAB & 10.4 & 10.7 & 10.5 & 10.6 & 0.4 & NS & $\mathrm{NS}$ \\
\hline \multirow{2}{*}{ Glu } & LAB & 8.4 & 8.1 & 8.3 & 8.2 & 0.2 & ** & NS \\
\hline & SAB & 8.3 & 8.5 & 8.6 & 8.2 & 0.3 & NS & $\dagger$ \\
\hline \multirow[t]{2}{*}{ Ser } & LAB & 5.8 & 5.9 & 5.8 & 5.9 & 0.3 & NS & NS \\
\hline & SAB & 5.8 & 5.9 & 5.8 & 5.9 & 0.2 & NS & NS \\
\hline \multirow[t]{2}{*}{ Thr } & LAB & 6.1 & 6.3 & 6.2 & 6.1 & 0.2 & NS & NS \\
\hline & $\mathrm{SAB}$ & 6.1 & 6.1 & 6.0 & 6.2 & 0.2 & NS & * \\
\hline \multirow[t]{2}{*}{ Gly } & LAB & 10.2 & 9.9 & 10.1 & 10.0 & 0.2 & $* * *$ & $\mathrm{NS}$ \\
\hline & $\mathrm{SAB}$ & 10.2 & 10.1 & 10.2 & 10.2 & 0.2 & NS & NS \\
\hline \multirow[t]{2}{*}{ Ala } & LAB & 11.4 & 11.3 & 11.4 & 11.2 & 0.2 & NS & NS \\
\hline & $\mathrm{SAB}$ & 11.5 & 11.5 & 11.7 & 11.4 & 0.3 & NS & $\dagger$ \\
\hline \multirow{2}{*}{ Arg } & LAB & 3.6 & 3.4 & 3.5 & 3.5 & 0.1 & $\dagger$ & NS \\
\hline & $\mathrm{SAB}$ & 3.7 & 3.6 & 3.6 & 3.6 & 0.1 & $\dagger$ & NS \\
\hline \multirow{2}{*}{ Pro } & LAB & 4.2 & 4.1 & 4.2 & 4.0 & 0.3 & NS & NS \\
\hline & SAB & 4.2 & 4.1 & 4.2 & 4.1 & 0.1 & $\dagger$ & NS \\
\hline \multirow[t]{2}{*}{ Val } & LAB & 5.6 & 5.6 & 5.6 & 5.7 & 0.4 & NS & NS \\
\hline & SAB & 5.5 & 5.5 & 5.5 & 5.5 & 0.1 & NS & $\mathrm{NS}$ \\
\hline \multirow[t]{2}{*}{ Met } & LAB & 1.2 & 1.3 & 1.3 & 1.2 & 0.1 & NS & NS \\
\hline & SAB & 1.2 & 1.2 & 1.3 & 1.2 & 0.2 & NS & $\mathrm{NS}$ \\
\hline \multirow[t]{2}{*}{ Ile } & $\mathrm{LAB}$ & 4.7 & 4.9 & 4.9 & 4.7 & 0.2 & $*$ & NS \\
\hline & SAB & 4.8 & 4.5 & 4.5 & 4.7 & 0.2 & $*$ & $\dagger$ \\
\hline \multirow[t]{2}{*}{ Leu } & LAB & 6.2 & 6.3 & 6.4 & 6.2 & 0.2 & NS & $\dagger$ \\
\hline & $\mathrm{SAB}$ & 6.2 & 6.1 & 6.2 & 6.1 & 0.1 & NS & NS \\
\hline \multirow[t]{2}{*}{ Phe } & LAB & 3.5 & 3.5 & 3.5 & 3.5 & 0.1 & NS & NS \\
\hline & $\mathrm{SAB}$ & 3.5 & 3.5 & 3.5 & 3.5 & 0.1 & NS & NS \\
\hline \multirow[t]{2}{*}{ Lys } & $\mathrm{LAB}$ & 11.7 & 12.4 & 12.0 & 12.1 & 0.6 & $*$ & NS \\
\hline & $\mathrm{SAB}$ & 11.3 & 11.3 & 11.1 & 11.5 & 0.4 & NS & $*$ \\
\hline \multirow[t]{2}{*}{ His } & LAB & 2.6 & 2.5 & 2.6 & 2.5 & 0.2 & NS & NS \\
\hline & $\mathrm{SAB}$ & 2.7 & 2.5 & 2.6 & 2.6 & 0.2 & NS & NS \\
\hline \multirow[t]{2}{*}{ Tyr } & LAB & 4.4 & 4.4 & 4.4 & 4.4 & 0.3 & NS & NS \\
\hline & SAB & 4.5 & 4.6 & 4.6 & 4.5 & 0.2 & NS & $\mathrm{NS}$ \\
\hline \multirow[t]{2}{*}{$\mathrm{EAA}^{3}$} & $\mathrm{LAB}$ & 45.2 & 46.3 & 45.9 & 45.5 & 0.1 & $\dagger$ & NS \\
\hline & SAB & 45.0 & 44.5 & 44.4 & 45.1 & 0.8 & NS & NS \\
\hline \multirow[t]{2}{*}{$\mathrm{NEAA}^{4}$} & $\mathrm{LAB}$ & 54.8 & 53.7 & 54.1 & 54.5 & 1.1 & $\dagger$ & NS \\
\hline & $\mathrm{SAB}$ & 55.0 & 55.5 & 55.6 & 54.9 & 0.8 & NS & NS \\
\hline
\end{tabular}

\footnotetext{
${ }^{1} \mathrm{HF}=$ High fiber; $\mathrm{LF}=\mathrm{lw}$ fiber.

${ }^{2} \mathrm{LS}=$ Large particle size; $\mathrm{SS}=$ small particle size.

${ }^{3} \mathrm{EAA}=$ Essential AA (Thr, Arg, Val, Met, Ile, Leu, Phe, Lys, and His).

${ }^{4} \mathrm{NEAA}=$ Nonessential AA (Ala, Asp, Glu, Gly, Pro, Ser, and Tyr).

$\dagger P<0.10$.

$* P<0.05$.

$* * P<0.01$
}

Changes in the purine and $\mathrm{N}$ concentrations in LAB and SAB may affect the magnitude and the significance of the differences in estimates of $\mathrm{N}$ metabolism in fermenters. Although numerical differences between estimates of $\mathrm{N}$ metabolism had the same direction, the magnitude of these differences was higher in SAB than in LAB. The standard error of most measurements in $\mathrm{SAB}$ was larger than that in LAB and was probably due to either incomplete or altered recovery of the microbial population through the bacteria detachment procedures. The differences observed in microbial composition between $\mathrm{LAB}$ and $\mathrm{SAB}$ suggest that many of the estimates of $\mathrm{N}$ metabolism changed more because of the microbial population considered than because of the main factors studied. Therefore, the identification of significant effects depended on the microbial population selected for calculations. These observations indicate the importance of obtaining representative samples of the microbial population including the LAB and SAB.

\section{Effects on the AA Profile and Flow}

Total flow of AA in effluents. Fiber content and particle size did not affect the flow (g/d) of essential (EAA), non-essential (NEAA), nor most individual AA (Table 6). Clark et al. (1992) indicated that, because of 
Table 8. Differences in amino acid flow (g/d) of microbial origin between solid-associated bacteria (SAB) and liquid-associated bacteria (LAB) in continuous culture.

\begin{tabular}{lllll}
\hline & \multicolumn{2}{c}{ Bacteria } & & \\
\cline { 2 - 3 } AA flow, g/d & LAB & SAB & SEM $^{1}$ & Effect $(P<)$ \\
\hline Asp & 0.62 & 0.77 & 0.05 & $* * *$ \\
Glu & 0.73 & 0.86 & 0.05 & $*$ \\
Ser & 0.32 & 0.37 & 0.02 & $* *$ \\
Thr & 0.39 & 0.45 & 0.02 & $*$ \\
Gly & 0.34 & 0.39 & 0.02 & $*$ \\
Ala & 0.46 & 0.55 & 0.03 & $* *$ \\
Arg & 0.33 & 0.40 & 0.02 & $* *$ \\
Pro & 0.20 & 0.24 & 0.01 & $*$ \\
Val & 0.46 & 0.52 & 0.03 & $*$ \\
Met & 0.13 & 0.15 & 0.01 & $\dagger$ \\
Ile & 0.42 & 0.47 & 0.02 & $*$ \\
Leu & 0.49 & 0.57 & 0.03 & $*$ \\
Phe & 0.30 & 0.35 & 0.02 & $*$ \\
Lys & 0.54 & 0.59 & 0.04 & NS \\
His & 0.10 & 0.12 & 0.01 & $* * *$ \\
Tyr & 0.27 & 0.32 & 0.02 & $* *$ \\
EAA & 3.15 & 3.62 & 0.19 & $*$ \\
NEAA & 2.94 & 3.50 & 0.19 & $* *$ \\
Total & 6.10 & 7.12 & 0.38 & $*$ \\
\hline
\end{tabular}

${ }^{1}$ Standard error of the mean of differences between SAB and LAB. ${ }^{2} \mathrm{EAA}=$ Essential AA (Thr, Arg, Val, Met, Ile, Leu, Phe, Lys, and His).

${ }^{3} \mathrm{NEAA}=$ Nonessential AA (Ala, Asp, Glu, Gly, Pro, Ser, and Tyr). $\dagger P<0.10$.

$* P<0.05$.

$* * P<0.01$.

$* * * P<0.001$.

the large contribution of microbial protein to the total AA flow, it was difficult to modify the AA profile in the digesta unless large amounts of supplemental ruminal undegradable protein sources were fed. In the present study, between 39.7 and $52.4 \%$ of the protein leaving the fermenters was of microbial origin, and diets did not contain supplemental undegradable protein sources. The flow of Asp, Glu, and Tyr was higher $(P<$ $0.05)$ in the LF diets, resulting in a trend for higher NEAA flow in LF diets compared with HF diets $(P<$ $0.10)$. The flow of Leu tended to increase $(P<0.10)$ in LF diets compared with HF diets and was attributed to the higher Leu content of corn (Rulquin and Vérité, 1993).

Effects on the AA profile of microbial origin. The $\mathrm{AA}$ profile of LAB and SAB (Table 5) was within the ranges reported by Clark et al. (1992), except for Ser, Gly, Ala, and Lys, which were higher in both bacterial groups, and Asp, Arg, Glu, and Phe, which were lower in both bacterial groups. Between-population comparisons indicated that the concentration of Asp, Ala, and Arg was higher $(P<0.05)$, that of His and Tyr tended to be higher $(P<0.10)$, and that of Lys was lower $(P<$ $0.05)$ in SAB compared with LAB. However, the numerical differences between microbial populations were smaller, and the number of AA that differed were fewer, than data reported by Martin et al. (1996), who reported a larger difference in 7 of 11 EAA or semi-essential AA depending on the time of sampling ( 2 vs. $23 \mathrm{~h}$ postfeeding) and in 6 of $11 \mathrm{AA}$ depending on the type of diet (hay vs. hay and barley).

Fiber content and particle size had a small effect on the profile of essential AA from LAB and SAB (Table 7 ). The interaction of fiber content $\times$ particle size was only significant for the proportion of Thr and Lys in LAB. The proportion (g AA/100 g AA) was 5.97, 6.18, 6.41, and 6.11, for Thr, and 11.31, 12.07, 12.72, and 12.12 for Lys in $\mathrm{HF}+\mathrm{LS}, \mathrm{HF}+\mathrm{SS}, \mathrm{LF}+\mathrm{LS}, \mathrm{LF}+$ SS, respectively. Results of other AA are presented by main effects.

The AA profiles of $\mathrm{LAB}$ and $\mathrm{SAB}$ were different in $\mathrm{HF}$ and LF $(P<0.05)$ in 5 of $16 \mathrm{AA}$ studied. However, the numerical differences were small and dependent on the bacterial population considered (Table 7). In $\mathrm{LAB}$, the profiles (g AA/100 g AA) of Asp, Glu, and Gly were higher, and those of Ile and Lys were lower, in $\mathrm{HF}$ than in LF. In SAB, the proportion (g AA/100 g AA) of Ile was lower $(P<0.05)$ in LF than in HF. Overall, the proportion (g AA/100 g AA) of EAA was $2.43 \%$ lower $(P<0.10)$ in $\mathrm{HF}$ than in LF when LAB was used for calculations. In contrast, the concentration (g AA/100 g AA) of EAA was not affected by the content of fiber when SAB was used for calculations. However, these differences in AA profile were smaller than those reported by Hussein et al. (1995), who reported a higher concentration of AA in a pool of ruminal bacteria (LAB and $\mathrm{SAB}$ ) in a high forage diet (70\% corn silage) compared with a low forage diet (30\% corn silage).

Fiber content and particle size had a small effect on the AA profile of LAB and SAB. Lallés et al. (1992) and Martin et al. (1996) indicated that the AA composition of ruminal bacteria was a characteristic of each bacterial group and, therefore, difficult to change by dietary manipulation. Others (Ørskov, 1988; Putnam et al., 1997) reached the same conclusion when comparing the AA profile of $\mathrm{LAB}$ and a mixture of $\mathrm{LAB}$ and $\mathrm{SAB}$ obtained from animals fed different diets. In contrast, data summarized from literature reports (Storm and Ørskov, 1984; Clark et al., 1992) and some in vivo trials (Hussein et al., 1995) suggested that diet might affect the AA profile of ruminal bacteria. However, Clark et al. (1992) suggested that the differences observed in the AA profile of ruminal bacteria across different experiments might be related to differences in the methodologies used for microbial isolation, the microbial marker used, or the method of AA analysis.

Effects on the AA flow of microbial origin. The estimated flow of microbial AA was higher $(P<0.05)$ for 14 of 16 AA measured when SAB were used instead 
Table 9. Effect of fiber content and particle size of diets on the estimated flow of AA (g/d) of liquid-associated bacteria $(\mathrm{LAB})$ and solid-associated bacteria (SAB) in continuous culture.

\begin{tabular}{|c|c|c|c|c|c|c|c|c|}
\hline \multirow{2}{*}{$\mathrm{AA}$} & & \multicolumn{2}{|c|}{ Fiber content $^{1}$} & \multicolumn{2}{|c|}{ Particle size ${ }^{2}$} & \multirow[b]{2}{*}{ SEM } & \multicolumn{2}{|c|}{ Effect $(P<)$} \\
\hline & & $\mathrm{HF}$ & $\mathrm{LF}$ & $\mathrm{LS}$ & SS & & $\mathrm{F}$ & $\mathrm{S}$ \\
\hline \multirow{2}{*}{ Asp } & LAB & 0.75 & 0.51 & 0.54 & 0.71 & 0.22 & $\dagger$ & NS \\
\hline & SAB & 0.93 & 0.62 & 0.69 & 0.86 & 0.34 & NS & NS \\
\hline \multirow[t]{2}{*}{ Glu } & LAB & 0.86 & 0.62 & 0.66 & 0.82 & 0.15 & $\dagger$ & $\mathrm{N}$ \\
\hline & SAB & 1.04 & 0.70 & 0.78 & 0.96 & 0.37 & $\dagger$ & $\mathrm{N}$ \\
\hline \multirow[t]{2}{*}{ Ser } & LAB & 0.37 & 0.28 & 0.28 & 0.37 & 0.10 & NS & $\mathrm{NS}$ \\
\hline & SAB & 0.44 & 0.31 & 0.32 & 0.43 & 0.14 & $\dagger$ & $\mathrm{N}$ \\
\hline \multirow[t]{2}{*}{ Thr } & LAB & 0.45 & 0.34 & 0.35 & 0.44 & 0.13 & NS & NS \\
\hline & SAB & 0.54 & 0.36 & 0.39 & 0.51 & 0.18 & $\dagger$ & $\mathrm{NS}$ \\
\hline \multirow[t]{2}{*}{ Gly } & LAB & 0.39 & 0.29 & 0.29 & 0.39 & 0.12 & NS & $\mathrm{N}$ \\
\hline & SAB & 0.48 & 0.31 & 0.35 & 0.44 & 0.16 & $\dagger$ & $\mathrm{NS}$ \\
\hline \multirow[t]{2}{*}{ Ala } & LAB & 0.54 & 0.40 & 0.42 & 0.52 & 0.15 & $\dagger$ & NS \\
\hline & $\mathrm{SAB}$ & 0.67 & 0.44 & 0.50 & 0.62 & 0.23 & $\dagger$ & $\mathrm{N}$ \\
\hline \multirow[t]{2}{*}{ Arg } & LAB & 0.40 & 0.29 & 0.30 & 0.38 & 0.11 & $\dagger$ & $\mathrm{N}$ \\
\hline & $\mathrm{SAB}$ & 0.50 & 0.32 & 0.35 & 0.46 & 0.16 & $*$ & $\mathrm{~N}$ \\
\hline \multirow[t]{2}{*}{ Pro } & LAB & 0.24 & 0.17 & 0.18 & 0.22 & 0.07 & $\dagger$ & NS \\
\hline & SAB & 0.29 & 0.19 & 0.21 & 0.27 & 0.09 & $\dagger$ & $\mathrm{N}$ \\
\hline \multirow{2}{*}{ Val } & LAB & 0.53 & 0.39 & 0.40 & 0.52 & 0.16 & NS & $\mathrm{N}$ \\
\hline & $\mathrm{SAB}$ & 0.64 & 0.42 & 0.46 & 0.59 & 0.21 & $\dagger$ & $\mathrm{N}$ \\
\hline \multirow[t]{2}{*}{ Met } & LAB & 0.15 & 0.12 & 0.12 & 0.14 & 0.04 & NS & NS \\
\hline & SAB & 0.18 & 0.12 & 0.14 & 0.16 & 0.06 & $\dagger$ & $\mathrm{NS}$ \\
\hline \multirow[t]{2}{*}{ Ile } & LAB & 0.47 & 0.37 & 0.37 & 0.47 & 0.13 & NS & NS \\
\hline & SAB & 0.58 & 0.40 & 0.41 & 0.54 & 0.18 & $*$ & $\mathrm{NS}$ \\
\hline \multirow[t]{2}{*}{ Leu } & LAB & 0.57 & 0.42 & 0.44 & 0.55 & 0.16 & NS & NS \\
\hline & $\mathrm{SAB}$ & 0.69 & 0.45 & 0.50 & 0.64 & 0.22 & $\dagger$ & NS \\
\hline \multirow[t]{2}{*}{ Phe } & LAB & 0.35 & 0.26 & 0.27 & 0.33 & 0.09 & NS & NS \\
\hline & SAB & 0.43 & 0.28 & 0.31 & 0.39 & 0.14 & $\dagger$ & NS \\
\hline \multirow[t]{2}{*}{ Lys } & LAB & 0.61 & 0.48 & 0.48 & 0.62 & 0.16 & NS & NS \\
\hline & SAB & 0.73 & 0.48 & 0.52 & 0.69 & 0.23 & $\dagger$ & NS \\
\hline \multirow[t]{2}{*}{ His } & LAB & 0.12 & 0.08 & 0.09 & 0.11 & 0.03 & $\dagger$ & $\mathrm{NS}$ \\
\hline & $\mathrm{SAB}$ & 0.15 & 0.09 & 0.10 & 0.14 & 0.05 & $*$ & NS \\
\hline \multirow[t]{2}{*}{ Tyr } & LAB & 0.31 & 0.23 & 0.24 & 0.30 & 0.10 & NS & NS \\
\hline & $\mathrm{SAB}$ & 0.39 & 0.26 & 0.29 & 0.36 & 0.14 & $\dagger$ & NS \\
\hline \multirow[t]{2}{*}{$\mathrm{EAA}^{3}$} & $\mathrm{LAB}$ & 3.65 & 2.74 & 2.82 & 3.57 & 1.00 & NS & NS \\
\hline & SAB & 4.43 & 2.89 & 3.18 & 4.13 & 1.43 & $\dagger$ & NS \\
\hline \multirow[t]{2}{*}{ NEAA $^{4}$} & $\mathrm{LAB}$ & 3.46 & 2.49 & 2.62 & 3.33 & 1.00 & $\dagger$ & NS \\
\hline & SAB & 4.25 & 2.84 & 3.14 & 3.94 & 1.47 & $\dagger$ & $\mathrm{NS}$ \\
\hline \multirow[t]{2}{*}{ Total } & $\mathrm{LAB}$ & 7.11 & 5.24 & 5.44 & 6.90 & 2.00 & $\dagger$ & NS \\
\hline & SAB & 8.68 & 5.73 & 6.33 & 8.07 & 2.90 & $\dagger$ & NS \\
\hline
\end{tabular}

\footnotetext{
${ }^{1} \mathrm{HF}=$ High fiber; $\mathrm{LF}=$ low fiber.

${ }^{2} \mathrm{LS}=$ Large particle size; $\mathrm{SS}=$ small particle size.

${ }^{3} \mathrm{EAA}=$ Essential AA (Thr, Arg, Val, Met, Ile, Leu, Phe, Lys, and His).

${ }^{4} \mathrm{NEAA}=$ Nonessential AA (Ala, Asp, Glu, Gly, Pro, Ser, and Tyr).

$\dagger P<0.10$.

$* P<0.05$.
}

of LAB (Table 8). The average difference was $15 \%$ in EAA and 19\% in NEAA. Klusmeyer et al. (1991) also reported differences in the calculated amount of EAA from bacteria passing to the duodenum when using different bacterial population isolates (mixed, LAB, or $\mathrm{SAB}$ ) because of differences in the concentration of some $\mathrm{AA}$ in bacterial OM.

The proportion of Met and Lys of microbial origin flowing from the fermenters changed depending on the bacterial population used for calculations (4.13 and 4.69\% Met and 17.4 and $16.3 \%$ Lys, when using LAB and $\mathrm{SAB}$, respectively) and were close to the optimal level (5 and 15\%, for Met and Lys, respectively) recom- mended for optimal milk protein productions (Rulquin and Vérité, 1993; NRC, 2001) in SAB vs. LAB.

The flow of each individual AA of microbial origin depends on the measurements of AA concentration and the estimated flow of microbial DM. Therefore, results are largely dependent on the representativeness of the microbial sample obtained and the accuracy of the analysis of microbial marker and AA profile. The impact of these errors on the estimation of the supply of AA of microbial origin to the small intestine is important. Because the differences in the estimated AA flow of microbial origin $(\mathrm{g} / \mathrm{d})$ resulting from the use of $\mathrm{LAB}$ or $\mathrm{SAB}$ were larger than the actual differences in their 
AA profiles, the estimation of the microbial DM contribution to the total protein flow was more determinant to the differences than the actual differences in the AA composition of the 2 microbial populations. These data reinforce the recommendations of Martin et al. (1996), who indicated the need to improve the accuracy of measuring the total and partial contribution of each microbial fraction to the total flow of $\mathrm{N}$ to the small intestine. Results indicate that the estimation of the microbial protein synthesis in the rumen and factors affecting it and the relative contribution of each microbial population (LAB and $\mathrm{SAB}$ ) to the total flow of microbial protein are essential to improving the precision of the estimation of the flow of AA of microbial origin to the small intestine.

The effects of fiber content and particle size on the estimated flow of AA of microbial origin using LAB and $\mathrm{SAB}$ are presented in Table 9 . There were no effects of particle size on bacterial AA flow. The fiber content $x$ particle size interaction was significant for the estimated flow of Lys $(P<0.05)$ when LAB was used for the calculation and was lower in $\mathrm{HF}+\mathrm{LS}(0.45 \mathrm{~g} / \mathrm{d})$ and $\mathrm{LF}+\mathrm{SS}(0.45 \mathrm{~g} / \mathrm{d})$ vs. HF + SS $(0.78 \mathrm{~g} / \mathrm{d})$ and $\mathrm{LF}$ $+\mathrm{LS}(0.51 \mathrm{~g} / \mathrm{d})$.

The estimated flow (g/d) of Arg, Ile, and His of bacterial origin was lower in LF than in $\mathrm{HF}$ when $\mathrm{SAB}$ instead of LAB were used for calculations $(P<0.05$; Table $9)$. Total flow of AA (g/d) of microbial origin was lower $(P<0.05)$ in $\mathrm{LF}$ than in $\mathrm{HF}$, but differences in individual AA were dependent on the microbial population used for calculations. Particle size did not affect the estimated flow of total or individual AA of microbial origin.

The flow of AA of microbial origin was calculated by multiplying bacterial flow $(\mathrm{g} / \mathrm{d})$ by the AA profile (\%). Because differences in the AA profile (\%) between LAB and $\mathrm{SAB}$ were small, and differences in the estimated flow (g/d) of AA of microbial origin between LAB and $\mathrm{SAB}$ (dependent on purine bases:N; Table 4) were large, it can be concluded that differences in the estimation of microbial protein flow had a higher impact on the estimation of the flow of AA of microbial origin than the AA profile. Therefore, it appears that the acurate measurement of the purine content of bacteria is more important than the measurement of the AA profile in determining the relative contribution of bacterial AA to the total flow of AA from fermenters. In addition, the accurate estimation of the flow of AA of microbial origin requires the accurate estimation of the contribution of LAB and SAB to the total N flow to the small intestine.

\section{CONCLUSIONS}

Fiber content and particle size had no effect on $\mathrm{OM}$ and fiber digestion in continuous culture of rumen fluid.
High fiber diets had lower total VFA and higher acetate concentrations compared with LF diets. The LS diet had a higher proportion of acetate and acetate:propionate and a lower proportion of butyrate compared with the SS diets. These differences were independent of intake, dilution rates, and $\mathrm{pH}$. The effects of fiber content and particle size on microbial and dietary $\mathrm{N}$ flow, protein degradation, and EMPS were dependent on the microbial population used for calculations. The AA profile of microbial groups was relatively independent of diet. However, accurate estimation of microbial $\mathrm{N}$ flow and the partial contribution of each microbial population may affect the estimated flow of AA of microbial origin.

\section{REFERENCES}

Association of Official Aanalytical Chemists. 1990. Official Methods of Analysis. 15th ed. AOAC, Arlington, VA.

Balcells, J. J., J. M. Guada, J. M. Peiró, and D. S. Parker. 1992. Simultaneous determination of allantoin and oxypurines in biological fluids by high performance liquid chromatography. J. Chromatogr. 575:153-157.

Beever, D. E., D. F. Osbourn, S. B. Cammel, and R. A. Terry. 1981. The effect of grinding and pelleting on the digestion of Italian ryegrass and timothy by sheep. Br. J. Nutr. 46:357-370.

Bourquin, L. D., E. C. Titgemeyer, J. Van Milgen, and G. C. Fahey. 1994. Forage level and particle size effects on orchadgrass digestion by steers: II. Ruminal digestion kinetics of cell wall components. J. Anim. Sci. 72:759-767.

Bowman, J. G., and J. L. Firkins. 1993. Effects of forage species and particle size on bacterial cellulolytic activity and colonization in situ. J. Anim. Sci. 71:1623-1633.

Chaney, A. L., and E. P. Marbach. 1962. Modified reagents for determination of urea and ammonia. Clin. Chem. 8:130-132.

Clark, J. H., T. H. Klusmeyer, and M. R. Cameron. 1992. Microbial protein synthesis and flows of nitrogen fractions to the duodenum of dairy cows. J. Anim. Sci. 75:2304-2323.

Czerkawski, J. W. 1986. Degradation of solid feed in the rumen: Spatial distribution of microbial activity and its consequences. Pages 158-172 in Control of Digestion and Metabolism in Ruminants. L. P. Milligan, W. L. Grovum, and A. Dobson, ed. Prentice Hall, Englewood Cliffs, NJ.

Fahey, G. C. Jr., L. D. Bourquin, E. C. Titgemeyer, and D. G. Atwell. 1993. Postharvest treatment of fibrous feedstuffs to improve their nutritive value. Pages 715-766 in Forage Cell Wall Structure and Digestibility. H. G. Jung, D. R. Buxton, R. D. Hatfield, and J. Ralph, ed. ASA-CSSA-SSSA, Madison, WI.

Grant, R. J., V. F. Colenbrander, and D. R. Mertens. 1990. Milk fat depression in dairy cows: Role of particle size of alfalfa hay. J. Dairy Sci. 73:1823-1833.

Hoover, W. H. 1986. Chemical factors involved in ruminal fiber digestion. J. Dairy Sci. 69:2755-2766.

Hoover, W. H., P. H. Knowlton, M. D. Stern, and C. J. Sniffen. 1976. Effects of differential solid-liquid removal rates on fermentation parameters in continuous culture of rumen contents. J. Anim. Sci. 43:535-542.

Hussein, H. S., N. R. Merchen, and G. C. Fahey, Jr. 1995. Composition of ruminal bacteria harvested from steers as influenced by dietary forage level and fat supplementation. J. Anim. Sci. 73:2469-2473.

Hvelplund, T., and J. Madsen. 1985. Amino acid passage to the small intestine in dairy cows compared with estimates of microbial protein and undegraded dietary protein from analysis on the feed. Acta Agric. Scand. (Suppl). 25:20-35.

Jarrige R., E. Grenet, C. Demarquilly, and J. M. Besle. 1995. Les constituants de l'appareil végétatif des plantes fourragères. Pages 
25-81 in Nutrition des Ruminants Domestiques. R. Jarrige, Y. Ruckebusch, C. Demarquilly, M. H. Farce, and M. Journet, ed. Institut National de la Recherche Agronomique, Paris, France.

Jouany, J. P. 1982. Volatile fatty acids and alcohol determination in digestive contents, silage juice, bacterial cultures and anaerobics fermentor content. Sci. Aliments 2:131-144.

Klusmeyer, T. H., M. W. Ohl, and J. H. Clark. 1991. Effect of using particle-associated (PAB), fluid associated (FAB) or mixed rumen bacteria (MB) for calculating nutrient flow to the duodenum of dairy cows. J. Dairy Sci. 74(Suppl.1):248. (Abstr.)

Lallès, J. P., C. Poncet, and R. Toullec. 1992. Composition en acides amines des bactéries libres et des bactéries fixées aux particules alimentaires du retículo-rumen du veau sevré et du mouton recevant différentes rations. Ann. Zootech. 41:75-76.

Legay-Carmier, F., and D. Bauchart. 1989. Distribution of bacteria in the rumen contents of dairy cows given a diet supplemented with soya-bean oil. Br. J. Nutr. 61:725-740.

Martín, C., A. G. Williams, and B. Michalet-Doreau. 1994. Isolation and characteristics of the protozoal and bacterial fractions from bovine ruminal content. J. Anim Sci. 72:2962-2968.

Martin, C., L. Bernard, and B. Michalet-Doreau. 1996. Influence of sampling time and diet on amino acid composition of protozoa and bacterial fractions from bovine ruminal contents. J. Anim. Sci. 74:1157-1163.

Meng, Q., M. S. Kerley, P. A. Ludden, and R. L. Belyea. 1999. Fermentation substrate and dilution rate interact to affect microbial growth and efficiency. J. Anim. Sci. 77:206-214.

Minato, H., and T. Suto. 1978. Technique for fractionation of bacteria in rumen microbial ecosystem. II. Attachment of bacteria isolated from bovine rumen to cellulose powder in vitro and elution of bacteria attached thereform. J. Gen. Appl. Microbiol. 24:1-16.

National Research Council. 2001. Pages 43-104 in Nutrient Requirement of Dairy Cattle. 7th ed. Natl. Acad. Press, Washington, DC.

Nocek, J. E., and R. A. Kohn. 1988. In situ particle size reduction of alfalfa and thimothy hay as influenced by form and particle size. J. Dairy Sci. 71:932-945.

O'Connor, J. D., C. J. Sniffen, D. G. Fox, and W. Chalupa. 1993. A net carbohydrate and protein system for evaluating cattle diets: IV Predicting amino acid adequacy. J. Dairy Sci. 71:1298-1311.

Olubobokun, J. A., and W. M. Craig. 1990. Quantity and characteristics of microorganisms associated with ruminal fluid or particles. J. Anim. Sci. 68:3360-3370.

Olubobokun, J. A., W. M. Craig, and W. A. Nipper. 1988. Characteristics of protozoal and bacterial fractions from microorganisms associated with ruminal fluid or particles. J. Anim. Sci. 66:2701-2710.

Ørskov, E. R. 1988. Nutrición proteica de los rumiantes. Editorial Acribia, S. A. Zaragoza, Espaa.
Pérez, J. F., J. Balcells, M. Fondevila, and J. A. Guada. 1998. Composition of liquid- and particle-associated bacteria and their contribution to the rumen outflow. Aust. J. Agric. Res. 49:907-914.

Putnam, D. E., C. G. Schwab, M. T. Socha, N. L. Whitehouse, N. A. Kierstead, and B. D. Garthwaite. 1997. Effect of yeast culture in the diets of early lactation dairy cows on ruminal fermentation and passage of nitrogen fractions and amino acids to the small intestine. J. Dairy Sci. 80:374-384.

Rode, L. M., D. C. Weakley, and L. D. Satter. 1985. Effect of forage amount and particle size in diets of lactating dairy cows on site of digestion and microbial protein synthesis. Can. J. Anim. Sci. 65:101-111.

Rulquin, H., and R. Vérité. 1993. Amino acid nutrition of dairy cows: productive effects and animal requirements. Pages 55-77 in Recent Advances in Animal Nutrition. P. C. Garnsworthy and D. J. A. Cole, ed. Nottingham University Press, UK.

Russell, J. B. 1998. The importance of $\mathrm{pH}$ in the regulation of ruminal acetate to propionate ratio and methane production in vitro. J. Dairy Sci. 81:3222-3230.

Shaver, R. D., A. J. Nytes, L. D. Satter, and N. A. Jorgesen. 1986. Influence of amount of feed intake and forage physical form on digestion and passage of prebloom alfalfa hay in dairy cows. J. Dairy Sci. 69:1545-1559.

Siciliano-Jones, J., and M. R. Murphy. 1989. Production of volatile fatty acids in the rumen and cecum-colom of steers as affected by forage: Concentrate and forage physical form. J. Dairy Sci. 72:485-492.

Steel, R. G. D., and J. H. Torrie. 1988. Bioestadística: principios y prodecimientos. 2̂ Edición. McGraw-Hill. Inc., US.

Storm, E., and E. R. Ørskov. 1984. The nutritive value of rumen microorganisms in ruminant. 4 . The limiting amino acids of microbial protein in growing sheep determined by a new approach. Br. J. Nutr. 52:613-620.

Van Soest, P. J., J. B. Robertson, and B. A. Lewis. 1991. Methods for dietary fiber, neutral fiber and nonstarch polysaccharides in relation to animal nutrition. J. Dairy Sci. 74:3588-3597.

Vendrell, J., and F. X. Avilés. 1986. Complete amino acid analysis of protein by dabsyl derivatization and reversed-phase liquid chromatography. J. Chromatogr. 358:401-413.

Weller, R. A., and A. F. Pilgrim. 1974. Passage of protozoa and volatile fatty acids from the rumen of sheep and from a continuous in vitro fermentation system. Br. J. Nutr. 32:341-351.

Whitehouse, N. L., V. M. Olson, C. G. Schwab, W. R. Chesbro, K. D. Cunningham, and T. Lykos. 1994. Improved techniques for dissociating particle-associated mixed ruminal microorganisms from ruminal digesta solids. J. Anim. Sci. 72:1335-1343. 